Österreichische Akademie der Wissenschaften / Austrian Academy of Sciences AAS WORKING PAPERS IN SOCIAL ANTHROPOLOGY Volume 24

David N. Gellner

UNCOMFORTABLE ANTINOMIES: GOING BEYOND METHODOLOGICAL NATIONALISM IN SOCIAL AND CULTURAL ANTHROPOLOGY

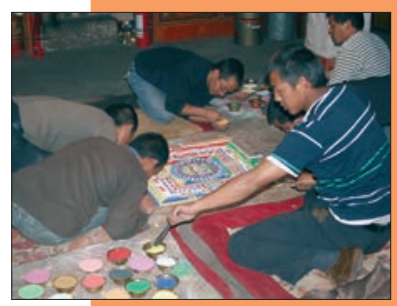




\section{AAS Working Papers in Social Anthropology / \\ ÖAW Arbeitspapiere zur Sozialanthropologie}

ISBN-Online: 978-3-7001-7276-5

doi:10.1553/wpsa24

Wien 2012

Editors / Herausgeber:

Andre Gingrich \& Guntram Hazod

(C) Institut für Sozialanthropologie

Zentrum Asienwissenschaften und Sozialanthropologie

Österreichische Akademie der Wissenschaften

Apostelgasse 24

A-1030 Wien

Fax: 01/ 51581-6450

E-Mail: sozialanthropologie@oeaw.ac.at 


\title{
UNCOMFORTABLE ANTINOMIES: GOING BEYOND METHODOLOGICAL NATIONALISM IN SOCIAL AND CULTURAL ANTHROPOLOGY
}

\author{
DAVID N. GELLnER
}

\begin{abstract}
How can ethnography be global? How can ethnography be anything but micro and ahistorical? It was designed to elucidate social processes in bounded communities or negotiated orders in institutions (...). By convention global ethnography can only be an oxymoron (Burawoy 2000: 1).
\end{abstract}

\section{Introduction}

This chapter considers some of the ways in which social and cultural anthropology has changed since its heyday in the immediate post-World War Two period. ${ }^{1}$ In particular, it focuses on the challenges to anthropological fieldwork methodology, with its stress on long-term stays in specific places, arising from the increasing mobility of people, ideas, and things - the process normally labeled globalisation. Just as practice theorists have argued for an irresolvable antinomy between structure and agency both sides of which must be embraced (Ortner 1990), I argue here that anthropologists must learn to live with uncomfortable but necessary antinomies (in the Kantian sense) between their face-to-face methods and the global issues they wish to address, and between their commitment to holism (with its associated dangers of methodological nationalism and/or ethnic groupism) on the one side, and the necessity of encompassing within their purview flux, movement, and change, on the other. Whether anthropologists couch their response to globalisation in terms of multi-sited ethnography (a methodological stance), global ethnography (a research programme), or in some other way, these antinomies cannot be avoided and should be embraced. Ethnographic exemplars are taken largely from the Asian contexts with which I am most familiar, but I hope that nothing advanced here depends on the particular cases considered.

\section{By going Global, Anthropology rejects Methodological Nationalism}

In 2001 Raman Roy, chief executive at a call centre in Delhi, was quoted as saying that geography is history. ${ }^{2}$ What he was referring to was the fact that vast quantities of information (and money) can be moved around the world at the click of a mouse, so there is no reason why

\footnotetext{
${ }^{1}$ This paper, presented at the Austrian Academy of Sciences' Institute for Social Anthropology (ISA), on 12th January 2012, is to be published in Ammelina, A., D.D. Nergiz, T. Faist, and N. Glick Schiller (eds.) 2012, Beyond Methodological Nationalism: Research Methodologies for Cross-Border Studies (Routledge Research in Transnationalism Series.), New York: Routledge, pp. 111-28. It is reproduced here with permission. The first three paragraphs of the second section are reproduced with permission from Gellner (2010a), the afterword to Acosta et al. (eds.), Making Sense of the Global (Cambridge Scholars Publishing). Thanks are due to D.P. Martinez, J. Pfaff-Czarnecka, and the editors of Beyond Methodological Nationalism, for detailed comments on earlier versions.

2 "Geography is history. Distance is irrelevant. Where you are physically located is unimportant. I can log on anywhere in the world" (Raman Roy in Harding 2001).
} 
UK householders should not talk to someone in Delhi (or wherever it is cheap to employ phone operators) in order to answer queries about their utility bills, renew their insurance, or get help with a malfunctioning computer. ${ }^{3}$ Physical distance is no longer a barrier to communication and consociality. Urban and suburban places that have airports and the internet have moved ever closer to each other; other places - those excluded from this instant connectivity - have moved, relatively, further apart. In this sense, Tokyo is much closer to London than it is to Siberia. ${ }^{4}$

Anthropologists have responded to this salience of 'the global' - the loss of 'the primitive' by studying people anywhere, not just in villages or nomad encampments. They now study up (Shore and Nugent 2002), sideways (Hannerz 2004), and in all different directions. They study Japanese business families (Hamabata 1990), the interlinked stories of countercultural mountaineers climbing Mt Everest and Sherpa social and religious change (Ortner 1999), British asylum courts (Good 2007), the inter-relationships and mutual influence of Japanese and Western films (Martinez 2009), and many more. Anthropologists study social movements, NGOs, activist networks and their interactions with the state (cf. Riles 2000; Gellner 2009a, 2010b). They study development practitioners (Mosse and Lewis 2005; Lewis and Mosse 2006) and policymakers (Shore and Wright 1997). They are now beginning to study the key economic institutions that both drive and constitute globalisation (cf. Sridhar 2008; Tett 2009; Ho 2009).

Anthropologists also move around more (or at least more openly) than they did in the past, following their subjects. Invoking George Marcus (1995), they frequently do 'multi-sited ethnography'. Transnationalism, process, and flow are in; what Malkki (1997: 61) has dubbed 'sedentarist metaphysics' are out. If the ethnographer encounters continuity, rootedness, or cohesive communities, these are not to be taken for granted but rather need to be explained as masks for powerful interests. Cohesion and consensus are assumed to be imposed and, if they are accepted, are presumed to be temporary.

Whether they are aware of it or not, what contemporary anthropologists are doing when they subject the notions of system, order, consensus, and bounded communities to sustained interrogation and suspicion is to reject methodological nationalism (sometimes they are also and consciously rejecting nationalism tout court). Since anthropologists are specialists in the small scale and the local, what they now reject has been called 'my tribe-ism', and might equally be called methodological ethnicism or tribalism (many anthropologists were in fact directly accused of 'tribalism', i.e. of encouraging tribalist feelings and undermining 'nation-building', by nationalists in the immediate postcolonial period). In other words, the besetting sin of anthropology in its classical and formative period was a kind of methodological nationalism writ small. Sociologists took national units for granted, anthropologists did the same for tribal ones. ${ }^{5}$ The usual 'emic' terms within the anthropological community for such old-fashioned views, now believed to have been superseded, are essentialism and functionalism.

Indeed, classic, mainstream social anthropology, as introduced by Malinowski in Britain, and

\footnotetext{
${ }^{3}$ Thomas Friedman's The World is Flat was a best-selling journalistic examination of the new connectivity. ${ }^{4}$ Cf. Giddens (1990) on space-time compression and the warnings of Favell (2001) and Brubaker (2005) against being carried away by metaphors of flux and change.

${ }^{5}$ Andre Gingrich (2010: 555) argues that anthropology has proved itself better at overcoming methodological nationalism than some neighbouring disciplines, such as sociology and philosophy.
} 
cultural anthropology as founded by Boas in the USA, did depend on the idea, derived ultimately from Herder, that each people had a particular 'genius' or ethos, expressed in unique language, customs, and traditions - in short a 'culture' - that set it off from other peoples. Many (such as Radcliffe-Brown) would have seen the distinctiveness more in terms of a particular social structure, rather than distinctive culture, but the effect was the same: to populate the map with discrete 'primitive' peoples, much as the map of Europe was divided up between nation-states. In that sense, twentieth-century anthropology (along with much of the rest of the social sciences) shared an intellectual inheritance with romantic nationalism, thus leading to what Richard Handler calls "the interpenetration of nationalist and social-scientific discourse" (Handler 1988: 8). ${ }^{6}$

Even today there are some anthropologists (perhaps particularly cultural anthropologists) who become specialists in one group, learn one language, and identify strongly with it, to the extent of becoming its lexicographer and/or political spokesperson. But, more commonly, contemporary anthropologists find themselves studying the whole process of the politicisation of ethnic identity, including the links of local activists to the capital city and with indigeneity movements worldwide (Warren 1998; Shah 2010). Anthropologists, particularly those who study groups claiming indigenous status, are faced with a moral quandary: whether to endorse those claims (and buy into the anthropologically unfashionable methodologically nationalist assumptions that underlie them) or rather to question and deconstruct the claims. Many try to ride both horses at once, supporting indigeneity claims, but in a lukewarm way, as a form of 'strategic essentialism'?

\section{Multi-sited vs. Global Ethnography}

George Marcus's (1995) call for multi-sited ethnography has been justifiably influential both within anthropology and well beyond it. There has been considerable discussion of Marcus's paper. Worries focus on whether constant movement on the part of the ethnographer will not make the resulting ethnography superficial, more like sociology, more concerned with bureaucracies and less with grasping and conveying alternative ways of viewing the world (Falzon 2009, Candea 2009, Marcus 2009).

Some have also pointed out that much of what is now called for was in fact done by classic anthropologists (Hannerz 2009). Indeed, anthropologists did not need the impact of globalisation, transnationalism, and postmodernism to legitimate travelling with their research subjects: anyone working on nomadic or semi-nomadic peoples (think of classics like Evans-Pritchard's The Nuer) will perforce have had to move around. Ethnography may be multi-sited even without the ethnographer moving around, if it takes place in a multicultural location (Baumann 1996). And the ethnographer may move around without ever leaving a single cultural bubble: such movement would be unlikely to satisfy Marcus's criterion of multi-sited ethnography - to engage with more than one place: i.e. with more than one set of contested cultural processes.

What Marcus's paper drew attention to was more than just movement, which has always existed: it argued that old senses of community and place had evaporated, or had at least been seriously attenuated by a new connectivity with the wider world. Thanks to this new connectivity, every-

\footnotetext{
${ }^{6}$ Thornton (1988) argues that there was also a very strong rhetorical commitment to writing ethnographic monographs in a holistic way.

${ }^{7}$ See Barnard (2006) and other articles in the same journal issue, discussing Kuper (2003).
} 
where being connected to everywhere else, there are no longer clearly defined 'sites'. 'The field is no longer objectively "out there". Rather one networks oneself into a concept of the field through relations of ethnographic research all the way along' (Marcus 2009: 193) - though, as Marcus himself immediately recognises, there is in fact a dialectic between the ethnographer's choices and the people, networks, and institutions studied.

Since it is no longer possible to pretend that the world is made up of discrete cultures, it is no longer enough for the ethnographer to stay put within a given culture, or even to move around within the confines of that culture. The only alternative is to follow people, things, metaphors, or plots as they move around between cultures. Thus, in recent years there have been many interesting examples of just such multi-sited ethnography following people (Levitt 2001), things (e.g. pharmaceuticals: Ecks and Basu 2009), or plots (e.g. remade cinema narratives: Martinez 2009).

Implicit in Marcus's paper is a distinction between places and spaces, a distinction often identified with Massey (1994) and theorised in Augé's book Non-Places. Places are spaces with meaning; non-places lack cultural meaning (sometimes the terminology is the other way around, but the distinction is the same). Similar distinctions between gender and sex, social and biological kinship, are well known to anthropologists - and often mistrusted and critiqued. Such distinctions will remain as long as anthropologists wish both to treat all humans as sharing certain universal capabilities and, on the other hand, as creatively producing different ways of interacting (cultures, in brief). Ethnographers try to tease out how that meaning is made and by whom.

Competing with Marcus's idea of multi-sited ethnography is the notion of global ethnography, particularly associated with the name of Michael Burawoy, an influential ethnographically inclined sociologist who has theorised the predicament in which anthropologists and qualitative sociologists find themselves. He has called specifically for a 'global ethnography' that builds on the case study method of the Manchester School (Burawoy 2000, 2009). He argues that ethnography, carried out in full awareness of various kinds of power and global forces, can overcome this oxymoronic dead end.

Gille and Ó Riain (2002) defend global ethnography with this same claim that it necessarily includes notions of power and history, as the rather flattening multi-site methodological injunction does not. The same virtues - incorporating history and power into ethnography against the Malinowskian vision - have also been claimed for practice theory and its attempt to combine bottom-up person- and meaning-centred ethnography with analyses of global economic and political processes (Ortner 1984, 1990). ${ }^{8}$

The discussion of multi-sited ethnography begins from the methodological choices facing fieldworking anthropologists in a rapidly changing world, whereas that on global ethnography starts from a subtly different place, namely the question of what qualitative researchers can contribute to understanding a rapidly changing and very unequal world. Reflecting these different starting points, the call for multi-sited ethnography is a methodological imperative,

\footnotetext{
${ }^{8}$ For a discussion of how Ortner, following Geertz, misconstrued Weber in this connection, see Gellner (2009c).
} 
whereas 'global ethnography' is a name for a research programme. But, as with practice theory, there are many who sail under the flag of global ethnography and the diversity of approaches adopted means that it is perhaps best understood as an aspiration rather than a theoretical school.

\section{Practising Ethnography in a Globalised World}

As modernisation proceeds, most societies experience the institutionalisation of some form of public-private dichotomy. The first task of the fieldworker who wants to be really embedded is to gain access to private households, ideally by living in one of them. But this is often problematic in modern societies. When my friend Rajendra Pradhan wished to study a Dutch village, he failed to find anyone willing to have a Nepali anthropologist living in their house (Pradhan 1990).

There are other considerations which may prevent the researcher from sharing everyday life with the people being studied. For example, when the aim is to study slumdwellers, conditions may just be too deprived for a fieldworker to share them and stay healthy, and a sick or depressed fieldworker is not an effective fieldworker. ${ }^{9}$ There are limits to the participant observation mantra - and not just in this connection.

More and more anthropologists are studying organisations and networks, rather than selfdefined cultural units, and having to adapt their methods accordingly (Gellner and Hirsch 2001). A practical way of considering the question of scale is to note that there are limits to the number of people one researcher can interact with. My colleague, Robin Dunbar, argues that, for evolutionary reasons, homo sapiens is capable of having meaningful relationships with around 150 people, and that the ability to handle that many is what distinguishes homo sapiens from apes and other species of homo (Dunbar 2008).

For the fieldworker, then, there are complex trade-offs and choices to be made in the field, where there are almost bound to be more than 150 people: which groups and which people to spend time with? The problem multiplies when one is obliged also to pursue global links. Why privilege one set of connections over another? Sometimes the field site provides a fairly obvious answer - when the aid agency that is so salient is connected to a particular place elsewhere - but in other cases it will not be so given. One person can only be in one place at a time, and can only carry on a limited number of relationships. Candea notes that the overwhelming choice of where to go and what to do during fieldwork meant that " 13 months went by with a constant sense of incompleteness and arbitrariness, the obsessive feeling of missing out, of vagueness and unjustifiable indeterminacy, of never being in the right place at the right time" (Candea 2009: 33). Even having studied a village in central Gujerat for three years and in team with two other co-workers, A.M. Shah (2002: 35) reflects: "We left the village with a sense of inadequacy at what we had accomplished, and humility when we realised how little we knew in relation to how much there was to be known."

Edmund Leach clearly concurred with the idea that a fieldworker can only handle a relatively small number of people:

\footnotetext{
${ }^{9}$ Moffatt (1979: xxiii-xliii) is a moving account of the impossibility of fieldwork under very deprived conditions.
} 
Fieldwork in this [anthropological] style is a very small-scale, private affair. The research 'team' is usually just a single individual, or perhaps a married couple, with maybe a local assistant. The field of study is a local community; perhaps just a hundred or so individuals, seldom many more than 2000. Initially the principal researchers must be strangers to the community; hopefully, before they depart, they will be just the reverse (Leach 1982: 129).

The first essential of intensive fieldwork is that the fieldworker should be able to recognise everyone in his vicinity (...). The second essential is that he should be able to gain most of his information by direct observation of how these people organise their day-to-day affairs both in space and time (ibid.: 145).

If Leach is right, the attempt to increase the scale of ethnography, to study, for example, in a city of 80,000, as I did in my doctoral work (Gellner 1992), is doomed to failure. But in fact, as the examples given above show, fieldwork has been done in situations Leach or Malinowski would not have recognised as anthropological, and the monographs that have resulted are often excellent. Collaborative work - teams of ethnographers working separately but to a shared the research agenda (very different from working together in the field) - is one way to tackle such social complexity (e.g. Gellner and Quigley 1995).

Like Levitt's (2001) transnational villagers, then, anthropologists engaging with 'the global' need to be able to live in two places at once. But can being in two places at once enable the kind of immersion the seeker after 'thick description' wants? Bob Simpson has described vividly how strange and different it is to do fieldwork while constantly being within Skyping range of one's family back home. "Part of the attraction of fieldwork for me," he writes, "is that it is a kind of experiment with selfhood - wiping the slate as clean as possible in order that others might write afresh on it" (Simpson 2009: 2). The more 'in touch' one is with home, the less likely one is to have the total immersion in another way of life that is necessary for truly holistic fieldwork. That distance, that difference, that ability to go somewhere really far away and wholly cut off seems to be disappearing.

Globalisation brings the limits of holism into stark relief: even the most heroic fieldworker obviously cannot study the whole globe in a face-to-face way. Multi-sited fieldwork does not make this problem go away. Holism, as I have tried to indicate, is not a realistic practice for any but the smallest social units; it is, rather, a regulative ideal, a metaphor for methodological and disciplinary inclusiveness. It therefore needs to be recognised as an ideal, rather than a practice, and the role of the fieldworker's choices - arbitrary, from one point of view, but informed - in constructing the field must be consciously and explicitly recognised.

\section{Still Holistic after all these Years - as a Regulative Ideal}

A student in an ethnographic methods class at Brunel University in the early 1990s finally saw the light and blurted out: "So you mean: Doing ethnography is just hanging around and talking to people?!" To which the answer was, yes, hanging around and talking to people is necessary, but not sufficient, for ethnographic fieldwork. It is a commonplace of such classes that social anthropologists cannot just go and hang around somewhere - they must go with a question and a focus (implying a grasp of theory, some kind of framework for their research, and a background in works on the region and topic). At the same time they should remain open to unexpected and unanticipated connections beyond their immediate focus. In other words, they must always 
retain a commitment to viewing the environment in which they find themselves holistically. That environment includes the geographical region, the history of that region and the micro-locality, and - today, increasingly important to keep on board - transnational links, whether from below or above. World Bank decisions in Washington DC or those of a UN sub-committee in Geneva may have just as much of an impact on the 'reality on the ground' as more local state effects (Pfaff-Czarnecka 2007; Sridhar 2008).

In the wider social science marketplace, social and cultural anthropologists have achieved a grudging acceptance as experts in the face-to-face, micro levels of analysis, but of a distinctive kind. Anthropologists are not content to focus exclusively on certain aspects or slices of smallscale interaction (small sections of verbal interaction, particular kinds of physical behaviour), as some sociologists and psychologists do. Instead they seek always to embed their detailed accounts of local practice in a wider context. The fact that the wider context now frequently includes unmediated connections all over the world is what lies behind the rise of global ethnography. Anthropologists have always sought both to be obsessive and complete about some particular order of social facts and at the same time to give an account of the whole or at least of the links to some wider whole. This means - as I put it in another context - that anthropological fieldworkers are necessarily cross-eyed, one eye focusing obsessively and systematically on the particular area of research concern, the other roving restlessly around for links, contrasts, and enlightenment in the wider environment (Hirsch and Gellner 2001: 7). ${ }^{10}$

And yet there is something in the social anthropological method that does indeed require a certain amount of apparently aimless hanging around. The very fact that social anthropologists are supposed to be interested in everything means that there is a commitment to allowing questions to arise from the material, and to follow the questions. This is opposed to the more common social scientific procedure of imposing a framework from the start and never reflecting on whether the concepts and methods with which the enquiry began are indeed fit for purpose. Sometimes it is necessary to hang around long enough for people to feel comfortable articulating what really concerns them. Geertz (1998) tried to dignify this slow, wait-and-see anthropological anti-method with the moniker 'deep hanging out'.

All this means that, from the point of view of other social sciences, ethnography can seem like the no-method method. Participant observation, like global ethnography, has always been something of an oxymoron: for most activities, either one participates or one observes, but doing both at once is humanly impossible. The term remains valuable for its indication that one should observe while participating in the way of life of those observed. It remains true that, with its openness, and aspiration to completeness, ethnography is an impossible task, a grasping after completeness that can never be achieved. At least when studying small groups, the aim may not be quite so hubristic. In the face of great social complexity and in the light of globalisation, it may seem positively foolhardy. ${ }^{11}$

\footnotetext{
${ }^{10}$ For more on anthropology's distinctiveness as a social science, deriving from this openness to what research participants or 'informants' tell us, see Gellner (2009b).

${ }^{11}$ In the light of this, Gille and Ó Riain's (2002: 273) claim that "[e]thnography is uniquely well placed to deal with the challenges of studying social life under globalization", because it enables the researcher to jump scales of analysis, is particularly bold.
} 
In spite of the criticisms that are frequently and justifiably levelled at ethnographic monographs, we know that they do sometimes succeed, so it is worth considering how this is achieved. If we accept that knowledge is sometimes attained, what are the conditions of possibility of that knowledge? ${ }^{12}$ I consider three factors - youth, gender, and persistent individualism - that help in the anthropological endeavour and the corresponding factors - age, gender again, and the tyranny of scientific models - that hinder it. Globalisation itself, by removing even the illusion of small and self-contained communities, is also making the holistic ideal harder to live up to. Indeed some anthropologists argue that we should abandon the holistic ideal altogether (Cook et al. 2009).

\section{Anthropological Fieldwork: A young Person's Game, perhaps even a young Woman's Game}

The time and emotional commitments required mean that participant observation is very difficult to put into practice, and it has been argued that multi-sited ethnography is so antithetical to the method as actually to undermine it (Candea 2009). Many people are temperamentally unsuited to it at any time of life, for others it is appropriate when young. There are a few heroic fieldworkers who manage to continue intense, long-term fieldwork well into old age. Margaret Mead is a debatable hero to hold up in this regard. Johnny Parry of the LSE is someone who has certainly managed it in three radically different kinds of field site spread right across very different parts of northern India ('traditional' village ethnography, premier pilgrimage centre, and Nehruvian steel town) - though I observe that even his production of ethnographic monographs has slowed as he has got older (compare Parry 1979, 1994, and 2001). For most of us, later fieldwork is less intense, less long-term, less personally transformative, and more collaborative, more reliant on accumulated experience, and more built on second-hand knowledge as opposed to first-hand experience.

In short, the claim advanced here is that first fieldwork is the most participatory, the most detailed, perhaps the most mistake-ridden, but in many ways, the best, in the sense that it generally produces the most impressive, detailed, and lasting ethnographic monographs (in many cases the author's only ethnographic monograph). In passing, let me note that ethnography may not just be age-related in this way, but possibly gender-related also. In the field of the ethnography of Nepal and South Asia, I have often been struck by the fact that a very large number of the best and most sensitive ethnographies are written by women. In the Nepal case, it is noticeable that many of the best ethnographies are also written by ex-Peace Corps volunteers, who have lived for years in Nepali villages, speak the languages very well, and then return for doctoral fieldwork. I am not saying here, what one can imagine might have been said in Malinowski's day, that women are good at ethnography but men are better at theory. To remain within the South Asian field, one can think of no more theoretically challenging, original, and significant detailed ethnography in the post-Dumontian era than Gloria Goodwin Raheja's Poison in the Gift (1988), for example. However, I do assert that the bar is continually being raised in terms of highquality, theoretically sophisticated ethnography, and it is noticeable that a very large proportion of these new ethnographies are by women.

Fieldwork requires a kind of total immersion that, as noted, comes easier for the young, because

${ }^{12}$ I leave to one side the by now well-trodden argument that 'success' is entirely constructed through persuasive rhetoric. 
they are encumbered neither by personal responsibilities nor by job duties that pull them away. The young have another advantage: they fit much more readily into the student role. In most societies hanging out, learning, apprenticing oneself, picking things up as one goes along all these are activities expected of young people. It is a comfortable position for the young ethnographer to inhabit - both for the ethnographer and for her hosts. As one gets older it is harder and harder to fit into the inconspicuous role of 'junior person needing to be instructed'. The older you are, the more you are expected to be authoritative, to teach, to know. I have frequently had the experience of being pushed into the role of the 'one who knows', a vidvan (scholar) in the north Indian vernaculars. In fact, so often did I go to meetings, trying to sit unobtrusively at the side and take notes, and find myself ushered to the front and on to the stage, and then requested to give a speech, that I thought I had better make a virtue out of a necessity and actually formally start to study activists and meetings. ${ }^{13}$

\section{The Tyranny of Collective Research and Scientific Models}

Anthropologists are familiar with the criticism from other social sciences: they collect anecdotal evidence, stories, small $\mathrm{N}$ samples, therefore their results are amusing but not widely applicable, appropriate subject matter for after-dinner speeches perhaps, but hardly serious scholarship. The tension between the personalistic interaction that is the bedrock of socio-cultural data-gathering and the big, widely applicable conclusions that anthropologists would like to draw amounts to one of several uncomfortable antinomies with which anthropologists must live.

Methodologically, this antinomy can push anthropologists in an overly scientific direction. One way in which this happens is through the dominance of a model of research activity that overvalorises teamwork. Some big funding councils give the impression that they are no longer interested in giving small amounts of money to send a lone researcher off for two years. They want collaborative team efforts (preferably international and interdisciplinary). But doing fieldwork in a big group, or even a small group of two or three people, prevents the complete immersion and identification (not to mention linguistic adaptation) that the lone researcher is forced to make. There is a tradition of whole classes of anthropology students descending on 'traditional' villages in Japan, for example, and perhaps in Navaho reservations in the past. Apparently, the inhabitants of the shanty town outside the gates of JNU in Delhi are equally used to being studied by Master's students appearing with clipboards. Such frequent or highdensity surveying, where those being studied perform their expected roles for short periods in front of the researcher or graduate seminar, cannot produce the kind of ethnography that social and cultural anthropologists are after. For that, loneliness and identification on the part of the researcher are essential.

Allied to the pressure for teamwork is the pressure for quick results. This has led to numerous adaptations of anthropological methods for use in development - Rapid Rural Appraisal, and so on. Such methods may be valuable for limited purposes and in the hands of experienced professionals, but they have never been known to produce rich ethnography - except ethnography of the aid world itself. The virtues of studies such as David Mosse's Cultivating Development (2005) or Celayne Heaton Shrestha's work on NGOs in Nepal $(2002,2006)$ depend rather more

${ }^{13}$ See Gellner and Karki (2007, 2008), Gellner (2009a, 2010b), and the MIDEA project on democratisation: www.uni-bielefeld.de/midea. 
on traditional participant observation carried out in the NGO and INGO office contexts than they do on any PRA methods.

Another very important tendency that undermines and interferes with ethnography is the drive to achieve scientific and quantifiable results. This is closely linked to the preference for teamwork, but it is a deeper tendency and is wider and more pervasive in its effects. The more one seeks to control and quantify the data, the more one's methods get in the way of listening, following, and falling in with what people themselves wish to talk about and do. The most essential qualities for good fieldwork are time, patience, and a willingness to go with the flow, abandoning preconceived plans. One can hardly imagine a methodological approach more inimical to the puritan drive for testing, results, and the accumulation of data. There is, therefore, a vital and inherent contradiction between the search for replicable results and the ability to engage in an ongoing human way, person to person, with 'research subjects'. This is not to suggest that there is no place for quantification in ethnographic research; nor does it imply that the ethnographer should abandon all concern to demonstrate how representative her findings are. Rather, it is to suggest that the best ethnography combines multiple frames of reference and that the humanistic, person-centred frame is not an optional extra or a mere tool for gaining access, but is at the very heart of the enterprise. The advocates both of multi-sited ethnography and of global ethnography recognise this primacy of the person-centred approach.

\section{Ethnography and Borders}

Anthropology has long been interested in those who cross boundaries and in marginal populations. More recently, geographers, sociologists, and anthropologists have all participated in the transnationalist vogue that has brought trans-border movement to the centre of attention and given it an important place in sociological theorising. But, in much of the world, it is only rather recently that those who actually live at political borders (as opposed to migrants) have been studied in conjunction with a focus on the state (e.g. Wilson and Donnan 1998; van Schendel 2005).

If indeed methodological nationalism is the besetting sin of contemporary social science, where better to make visible the action of the state, and the fact that it is carefully orchestrated, than at borders where two or more sets of 'state effects' come into contact and/or conflict? In fact, it is likely to be at borders also that various forms of resistance are also encountered (Abraham and van Schendel 2005) as well as sheer indifference to and ignorance of the state, not to mention exaggerated loyalty (Aggarwal 2004), depending on the kind of border we are talking about. For those interested in global connections, border locations are an attractive place to start.

Borderlanders often confound the expectations both of states and of methodological nationalists. Ethnic groups merge into one another, or undergo kaleidoscopic shifts at unnerving speed. Populations move around and cannot be fixed (Scott 2009). Some states maintain enclaves, tiny pockets of land surrounded by the territory of the neighbouring state, where people are either left stateless or with citizenship but unable to access it. Van Schendel has documented the extraordinary case of the India-Bangladesh border with its 123 pockets of Indian land inside Bangladesh and 74 Bangladeshi enclaves surrounded by Indian territory (van Schendel 2002, 2005). 
Some ethnographic work has been done at borders, ${ }^{14}$ but far more remains to be done, and the complexity of the work probably does require teams of researchers working separately but in tandem at different sites. For obvious reasons, many states limit access to their border areas, which accounts for the relatively paucity of ethnographies in frontier zones. But if they can be accessed, such sites offer the possibility of observing global and national processes distilled. What needs to be avoided is the assumption that all borderlands are the same - defined by their distance from the metropolis. Attempts to seek a single 'borderland theory' risk reproducing nationalist and 'sedentarist' assumptions; border situations are multiple (internal borders may equally be highly significant) and can only be interpreted in relation to diverse state-making strategies. Borders are also a reminder to anthropologists that the world is not one seamless network: some people can access both sides, others cannot, and issues of power and history are never far away.

\section{Conclusion: Uncomfortable but Necessary Antinomies}

Many have noticed that the contemporary interest in and emphasis on flow and global movement (Hannerz 1997) has effectively taken anthropologists back to the position of the nineteenthcentury diffusionists. As Falzon (2009: 5) remarks, "one can only hope that history will judge us to have been less speculative." Yet the reasons why diffusionism was so firmly rejected in the post-war period need to be remembered. Treating culture as a thing of shreds and patches, not animated by any internal coherence and not worthy of being comprehended as a whole, simply did not produce good ethnographies: it led neither to the empathy necessary to understand local worldviews, nor to any rigorous way of analysing how a local culture fits together. At the same time, we have come to see the attempt to view cultures as isolated and autonomous as wrongheaded, ideologically motivated, and worse. In short, there is a structural antinomy between structuralist and functionalist holism on the one side and diffusionism on the other: both are necessary to good fieldwork. They pull in different directions, requiring our attention to be focused alternately on local meanings and transnational links. Neither can be ignored and the global ethnographer must live with such uncomfortable antinomies, ceding to the exclusivist claims of neither side, but learning to combine both in a creative tension.

Realistically, a single individual can only do rich fieldwork in one, two, or, if talented and possessed of superhuman energy, three sites. (Even a single site, where that site is a meeting place of numerous languages, is going to be beyond the competence of a single researcher to grasp in its entirety.) Comparison between them is likely to be by the simple method of difference and similarity (cf. Fitzgerald 2010). Anything more sophisticated requires new kinds of joint project where ethnographers design their questions and problems together, then work separately in the field, but share their results and publish together.

Global ethnography comprises two competing aspirations. On the one hand, there is an ongoing commitment to the virtues of structural-functionalist, holistic fieldwork, built on an individual really getting to know a new environment, speak the language, and come to feel at home. On the other hand, there is the hard-won consciousness that culture is not in fact a coherent and seamless web; the diffusionists of the nineteenth century and the world systems and transnational theorists

${ }^{14}$ See Martínez (1994) and Wilson and Donnan (1998). For a useful overview, see Baud and van Schendel (1997). 
of the twentieth were right to put flux, flow, and movement across boundaries at the centre of their analyses. Thus, global ethnography is indeed an oxymoron, but a necessary one; the phrase encapsulates the tension between grasping particular lived everyday worlds as they are experienced and, on the other hand, the knowledge and awareness that such local worlds are but a small part of multiple global processes. Living with that tension is, I have argued, a productive and necessary antinomy, however uncomfortable it sometimes makes us. Ethnographers must combine a data collection tool - participant observation - that has an inbuilt bias towards methodological nationalism and/or methodological ethnicism with a constant awareness of, and constant struggle to overcome, that inbuilt bias.

DAVID N. GELLnER is Professor of Social Anthropology at the University of Oxford and a Fellow of All Souls College. He was the Head of Department of the School of Anthropology and Museum of Ethnography in the University of Oxford from 2009 to 2012. His research interests include religion (especially Hinduism and Buddhism); social organisation; healing and spirit possession; the anthropology of activism, political violence, and the state; democratisation; borders; and diaspora populations. His recent publications include 'Fluidity, Hybridity, Performativity: How Relevant are Social-Scientific Buzzwords for Nepal's Constitution Building?' in C. Mishra and O. Gurung (eds.), Ethnicity and Federalization in Nepal (2012); Varieties of Activist Experience: Civil Society in South Asia (ed. 2010); his inaugural lecture, 'The Awkward Social Science? Anthropology on Schools, Elections, and Revolution in Nepal' (JASO-online, 2009); and 'The Uses of Max Weber: Legitimation and Amnesia in Buddhology, South Asian History, and Anthropological Practice Theory' in P. Clarke (ed.), The Oxford Handbook of the Sociology of Religion (2009). His most recent research project is on religion in the Nepali diaspora in the UK and Belgium. 


\section{Literature}

Abraham, I. and W. van Schendel (eds.). 2005. Illicit Flows and Criminal Things, Bloomington: Indiana University Press.

Aggarwal, R. 2004. Beyond Lines of Control: Performing Borders in Ladakh, India, Durham: Duke University Press.

Augé, M. 1995. Non-Places: Introduction to an Anthropology of Supermodernity, London: Verso.

Barnard, A. 2006. Kalahari Revisionism, Vienna, and the 'Indigenous Peoples' Debate, Social Anthropology 14(1): 1-16.

Baud, M. and W. van Schendel. 1997. Toward a Comparative History of Borderlands, Journal of World History 8(2): 211-42.

Baumann, G. 1996. Contesting Culture: Discourses of Identity in Multi-Ethnic London, Cambridge: Cambridge University Press.

Brubaker, R. 2005. The 'Diaspora' Diaspora, Ethnic and Racial Studies 28(1): 1-19.

Burawoy, M. 2000. Introduction: Reaching for the Global, in: M. Burawoy et al. (eds), Global Ethnography: Forces, Connections, and Imaginations in a Postmodern World, Berkeley: Univ. of California Press, pp. 1-40.

Burawoy, M. 2009. The Extended Case Method: Four Countries, Four Decades, Four Great Transformations, and One Theoretical Tradition, Berkeley: Univ. of California Press.

Candea, M. 2009. Arbitrary Locations: In Defence of the Bounded Field-site, in: M.-A. Falzon (ed.), Multi-Sited Ethnography: Theory, Praxis and Locality in Contemporary Research, Farnham: Ashgate, pp. 25-45.

Cook, J., J. Laidlaw, and J. Mair. 2009. What if there is no elephant? Towards a conception of an un-sited field, in: M.-A. Falzon (ed.) Multi-Sited Ethnography: Theory, Praxis and Locality in Contemporary Research, Farnham: Ashgate, pp. 47-72.

Dunbar, R. 2008. Mind the gap: or why humans aren't just great apes, Proc. Brit. Acad. 154: 403-23.

Ecks, S. and S. Basu. 2009. The Unlicensed Lives of Antidepressants in India: Generic Drugs, Unqualified Practitioners, and Floating Prescriptions, Transcultural Psychiatry 46(1): 86-106.

Evans-Pritchard, E.E. 1940. The Nuer: A Description of the Modes of Livelihood and Political Institutions of a Nilotic People, Oxford: Clarendon Press.

Falzon, M.-A. 2009. Introduction: Multi-Sited Ethnography: Theory, Praxis and Locality in Contemporary Research, in: M.-A. Falzon (ed.), Multi-Sited Ethnography: Theory, Praxis and Locality in Contemporary Research, Farnham: Ashgate, pp. 1-24.

Favell, A. 2001. Migration, Mobility and Globaloney: Metaphors and Rhetoric in the Sociology of Globalization, Global Networks 1(4): 389-98.

Fitzgerald, D.S. 2010. Mixed Methods and Crossing Boundaries in the Study of International Migration. COMCAD Working Papers 73 (http://pub.uni-bielefeld.de/publication/2317229).

Friedman, J. 2006. The World is Flat: The Globalized World in the Twenty-First Century, London: Penguin.

Geertz, C. 1998. Deep Hanging Out, The New York Review of Books (www.nybooks.com/articles/archives/1998/oct/22/deep-hanging-out/) (consulted 5/1/11). Reissued 2000 in: Available Light: Anthropological Reflections on Philosophical Topics, Princeton: Princeton Univ. Press. 
Gellner, D.N. 1992. Monk, Householder, and Tantric Priest: Newar Buddhism and its Hierarchy of Ritual, Cambridge: Cambridge University Press.

Gellner, D.N. (ed.) 2009a. Ethnic Activism and Civil Society in South Asia, Delhi: Sage.

Gellner, D.N. 2009b. The Awkward Social Science? Anthropology on Schools, Elections, and Revolution in Nepal, JASO-online (NS), 1(2): 115-40. (www.isca.ox.ac.uk/fileadmin/ISCA/JASO/1\%202_115-140_Gellner.pdf)

Gellner, D.N. 2009c. The Uses of Max Weber: Legitimation and Amnesia in Buddhology, South Asian History, and Anthropological Practice Theory, in: Clarke, P. (ed.), The Oxford Handbook of the Sociology of Religion, pp. 48-62, Oxford University Press.

Gellner, D.N. 2010a. Geography as History is also now History: Some Comments on Anthropology's Role in Making Sense of the Global, in: Acosta,R., S. Rizvi, and A. Santos (eds.), Making Sense of the Global: Anthropological Perspectives on Interconnections and Processes. Cambridge: Cambridge Scholars Press, pp. 195-205.

Gellner, D.N. (ed.). 2010b. Varieties of Activist Experience: Civil Society in South Asia, Delhi: Sage.

Gellner, D.N. and Hirsch, E. (eds.). 2001. Inside Organizations: Anthropologists at Work, Oxford: Berg.

Gellner, D.N. and Karki, M.B. 2007. The Sociology of Activism in Nepal: Some Preliminary Considerations, in: Ishii,H., D.N. Gellner, and K. Nawa (eds.), Political and Social Transformations in North India and Nepal: Social Dynamics in Northern South Asia, Volume 2. Delhi: Manohar, pp. 361-97.

Gellner, D.N. and Karki, M.B. 2008. Democracy and Ethnic Organizations in Nepal, in: Gellner, D.N. and K. Hachhethu (eds.), Local Democracy in South Asia: The Micropolitics of Democratization in Nepal and its Neighbours, Delhi: Sage, pp. 105-27.

Gellner, D.N. and D. Quigley. 1995. Contested Hierarchies: A Collaborative Ethnography of Caste among the Newars of the Kathmandu Valley, Nepal, Oxford: Clarendon.

Giddens, A. 1990. The Consequences of Modernity, Cambridge: Polity.

Gille, Z. and S. Ó Riain. 2002. Global Ethnography, Annual Review of Sociology 28: 271-95.

Gingrich, A. 2010. Transitions: Notes on Sociocultural Anthropology's Present and its Transnational Potential, American Anthropologist 112(4): 552-62.

Good, A. 2007. Anthropology and Expertise in the Asylum Courts, Abingdon: Routledge Cavendish.

Hamabata, M.M. 1990. Crested Kimono: Power and Love in the Japanese Business Family, Ithaca: Cornell University Press.

Handler, R. 1988. Nationalism and the Politics of Culture in Quebec, Madison: University of Wisconsin Press.

Hannerz, U. 1997. Flows, Boundaries, and Hybrids: Keywords in Transnational Anthropology, www.transcomm.ox.ac.uk/working\%20papers/hannerz.pdf (consulted 5/1/11).

Hannerz, U. 2004. Foreign News: Exploring the World of Foreign Correspondents, Chicago: University of Chicago Press.

Hannerz, U. 2009. Afterword: The Long March of Anthropology, in: Falzon, M.-A. (ed.), MultiSited Ethnography: Theory, Praxis and Locality in Contemporary Research, Farnham: Ashgate, pp. 271-82.

Harding, L. 2001. Delhi Calling, www.guardian.co.uk/g2/story/0,3604,448955,00.html (consulted $8 / 23 / 09$ ). 
Heaton Shrestha, C. 2002. NGOs as Thekadar or Sevak: Identity Crisis in Nepal's Non-governmental Sector, European Bulletin of Himalayan Research 22: 5-36.

Heaton Shrestha, C. 2006 'They Can't Mix Like We Can': Bracketing Differences and the Professionalization of NGOs in Nepal, in: Lewis, D. and D. Mosse (eds.), Development Brokers and Translators: The Ethnography of Aid and Agencies, Bloomfield CT: Kumarian, pp. 195216.

Hirsch, E. and Gellner, D.N. 2001. Introduction: Ethnography of Organizations and Organizations of Ethnography, in: Gellner, D.N. and E. Hirsch (eds.), Inside Organizations: Anthropologists at Work, Oxford: Berg, pp. 1-15.

Ho, K.Z. 2009. Liquidated: An Ethnography of Wall Street, Durham and London: Duke University Press.

Kuper, A. 2003. The Return of the Native, Current Anthropology 44(3): 389-95.

Leach, E. 1982. Social Anthropology, Fontana.

Levitt, P. 2001. The Transnational Villagers, Berkeley: Univ. of California Press.

Lewis, D. and D. Mosse (eds.) 2006. Development Brokers and Translators: The Ethnography of Aid and Agencies, Bloomfield, Conn.: Kumarian.

Malkki, L. 1997. National Geographic: The Rooting of Peoples and the Territorialization of National Identity among Scholars and Refugees, in: Gupta, A. and J. Ferguson (eds.), Culture, Power, Place: Explorations in Critical Anthropology, Durham, N.C.: Duke University Press, pp. 52-74.

Marcus, G.E. 1995. Ethnography in/of the World System: The Emergence of Multi-sited Ethnography, Annual Review of Anthropology, 24: 95-117 (Republished 1998 in his Ethnography through Thick and Thin, Princeton Univ. Press, pp. 79-104.

Marcus, G.E. 2009. Multi-Sited Ethnography: Notes and Queries, in: Falzon, M.-A. (ed.) MultiSited Ethnography: Theory, Praxis and Locality in Contemporary Research, Farnham: Ashgate, pp. 181-96.

Martinez, D.P. 2009. Remaking Kurosawa: Translations and Permutations in Global Cinema, New York: Palgrave Macmillan.

Martínez, O.J. 1994. Border People: Life and Society in the U.S.-Mexico Borderlands, Tucson: Univ. of Arizona Press.

Massey, D. 1994. Global Sense of Place, in her: Space, Place, and Gender, Cambridge: Polity.

Moffatt, M. 1979. An Untouchable Community in South India: Structure and Consensus, Princeton: Princeton Univ. Press.

Mosse, D. 2005. Cultivating Development: An Ethnography of Aid Policy and Practice, London: Pluto.

Mosse, D. and D. Lewis (eds.). 2005. The Aid Effect: Giving and Governing in International Development, London: Pluto.

Ortner, S.B. 1984. Theory in Anthropology since the Sixties, Comparative Studies in Society and History 26: 126-66 (Reissued 1994 in Dirks, N.B., G. Eley, and S.B. Ortner (eds.), A Reader in Contemporary Social Theory, Princeton: University Press, pp. 372-411.

Ortner, S.B. 1990. High Religion: A Cultural and Political History of Sherpa Buddhism, Princeton: Princeton University Press.

Ortner, S.B. 1999. Life and Death on Mt Everest: Sherpas and Himalayan Mountaineering, Princeton: Princeton University Press. 
Parry, J. 1979. Caste and Kinship in Kangra, London: Routledge.

Parry, J. 1994. Death in Banaras, Cambridge: Cambridge University Press.

Parry, J. 2001. Ankalu's Errant Wife: Sex, Marriage and Industry in Contemporary Chhattisgarh, Modern Asian Studies 35(2): 783-820.

Pfaff-Czarnecka, J. 2007. Challenging Goliath: People, Dams, and the Paradoxes of Transnational Critical Movements, in: Ishii, H., D.N. Gellner, and K. Nawa (eds.), Political and Social Transformations in North India and Nepal, Delhi: Manohar, pp. 421-57.

Pradhan, R. 1990. Much Ado about Food and Drinks: Notes towards an Ethnography of Social Exchange in the Netherlands, Ethnofoor, 3(2): 48-68.

Raheja, G.G. 1988. The Poison in the Gift: Ritual, Prestation, and the Dominant Caste in a north Indian Village, Chicago: the University of Chicago Press.

Riles, A. 2000. The Network Inside Out, Ann Arbor: University of Michigan Press.

Scott, J.C. 2009. The Art of Not Being Governed: An Anarchist History of Upland Southeast Asia, New Haven and London: Yale University Press.

Shah, A. 2010. In the Shadow of the State: Indigenous Politics, Environmentalism, and Insurgency in Jharkand, India, Durham: Duke University Press.

Shah, A.M. 2002. Studying the Present and the Past: A Village in Gujerat, in: Srinivas, M.N., A.M. Shah, and E.A. Ramaswamy (eds.), The Fieldworker and the Field: Problems and Challenges in Sociological Investigation, Delhi: OUP, pp. 29-37.

Shore, C. and S. Nugent (eds.). 2002. Elite Cultures: Anthropological Perspectives (ASA 38), London: Routledge.

Shore, C. and S. Wright (eds.). 1997. Anthropology of Policy: Critical Perspectives on Governance and Power, London: Routledge.

Simpson, B. 2009. Messages from the Field, Anthropology Today, 25(5): 1-3.

Sridhar, D. 2008. The Battle against Hunger: Choice, Circumstance, and the World Bank, Oxford: Oxford University Press.

Tett, G. 2009. Fool's Gold: How Unrestrained Greed Corrupted a Dream, Shattered Global Markets and Unleashed a Catastrophe, London: Little, Brown.

Thornton, R.J. 1988. The Rhetoric of Ethnographic Holism, Cultural Anthropology, 3(3): 285303.

van Schendel, W. 2002. Stateless in South Asia: The Making of the India-Bangladesh Enclaves, Journal of Asian Studies 61(1): 115-47.

van Schendel, W. 2005. The Bengal Borderland: Beyond State and Nation in South Asia, London: Anthem.

Warren, K.B. 1998. Indigenous Movements and their Critics: Pan-Maya Activism in Guatemala, Princeton: Princeton University Press.

Wilson, T. and H. Donnan (eds.). 1998. Border Identities: Nation and State at International Frontiers, Cambridge: Cambridge University Press. 